\title{
Japan's Peacebuilding and Mid-Space Actors: A Bridge Between the West and the Rest
}

\author{
Yuji Uesugi and Anna Deekeling
}

\section{INTRODUCTION}

In the previous chapters, it was discussed how the hybrid peacebuilding theory might transform existing approaches to peacebuilding. The aim was to solidify the theoretical framework of an operationalisation of the hybrid peacebuilding theory so that it can better address the realities of peacebuilding in Asia. In contrast, this chapter takes an inductive approach and examines Japan's approaches to peacebuilding, which is defined by the Japanese government as "consolidation of peace" and "nation-building" (MOFA 2007).

Before turning to the main task, three core premises of this study are recapitulated here. First, mid-space actors who enjoy access to different sources of power, both formal and informal, and maintain a deep cultural

Y. Uesugi $(\bowtie) \cdot A$. Deekeling Waseda University, Tokyo, Japan e-mail: uesugi@waseda.jp

A. Deekeling e-mail: annadeekeling@fuji.waseda.jp

(C) The Author(s) 2021

Y. Uesugi et al. (eds.), Operationalisation of Hybrid Peacebuilding in Asia, Security, Development and Human Rights in East Asia, https://doi.org/10.1007/978-3-030-67758-9_8 
and normative understanding of their community, can assume the function of a gatekeeper (Uesugi 2020). Second, these gatekeepers possess inherent characteristics that cannot be emulated by outsiders. These include transformative relationships (the ability and willingness to interact with key stakeholders outside one's immediate social sphere), locally grounded legitimacy (a collective trust of the constituency gained through their knowledge and power), and laissez-passer (a special access to information and resources that are closed to strangers). Third, depending on the circumstances, these gatekeepers become either bridge-builders who can cross over the existing cleavages or spoilers who can oppose and jeopardise ongoing peacebuilding efforts.

A logical corollary of these propositions is that outside intervenors need to identify mid-space actors and work with them and, if necessary and appropriate, help them serve as bridge-builders. This chapter is an attempt to evaluate Japan's peacebuilding efforts from that angle. The following sheds light on three cases of outstanding Japanese engagement with mid-space actors in conflict-affected localities in Asia-Timor-Leste, Myanmar and Mindanao, the Philippines. Features of Japan's peacebuilding approaches are outlined first, and then, empirical records of Japan's peacebuilding efforts in the above three cases are examined. Before concluding the chapter, the shortcomings of Japanese approaches are also discussed.

\section{Features of Japan's Peacebuilding}

This section highlights distinctive and unique characteristics of Japan's peacebuilding approach. An inherent trait of Japan's peacebuilding is found in the origin and the genesis of modern Japan, a non-Western nation-state located at the eastern offshore end of the Eurasian continent (Umesao 1957/1967). Japan's defeat in the Second World War (WWII), and most notably its post-war Constitution, has shaped the basic foundation of Japan's peacebuilding approach. In the following, features of Japan's peacebuilding approach are outlined from three angles: (1) historical traits, (2) aid architectures, and (3) three recurrent practices.

\section{Historical Traits as a Bridge-Builder}

Having undergone a difficult modernisation process in the nineteenth century and embarked on a costly colonisation of its neighbours in the 
first half of the twentieth century, Japan learned the lesson that the sense of emancipatory local ownership is a key to successful modernisation and development. Japan once endeavoured to establish the Great East Asia Co-prosperity Sphere, in which Japan was conceived to serve as a bridge between the colonial powers in Europe and their colonies in East Asia, with an aim of establishing an autonomous regional order that would emancipate East Asia from European control (Ikeda 2008). After this dream was shattered, Japan sought to present its representational selfimage as a peacebuilder in the post-WWII world (Iwami 2016). Along the same line, Japan has promoted its own capacity as a bridge-builder (Black 2013), this time, bridging between developed countries in the West and developing countries in general but especially in Southeast Asia. The Japanese government justifies this role not only through its geographical location but also through its own experience as a former developing country trying to catch up to the West in the nineteenth century, and in the aftermath of the fierce defeat of WWII.

Japan's own history of encounter with and infringement by the West, as well as its experience of post-war reconstruction under 'colonial arrogance' (Richmond 2018) of the US, has equipped Japan to refine international peacebuilding to be a more reflective and adaptive undertaking (de Coning 2018). Utilising its own experience of modernisation by adopting Western systems and adapting them to fit with the domestic context, Japan has projected itself as a great example of how to exploit outside intervention for its own advantage and prosperity.

\section{Aid Architectures}

Official Development Assistance (ODA) has been a substantial tool for Japan's peacebuilding efforts. Although ODA started mainly as reparation payments for WWII to Japan's neighbours, the Japanese government used it to promote its own economy through contracting Japanese companies for infrastructure and development projects in Asia (Reilly 2013). This is a prototype of a win-win approach that Japan advocates. Under the policy of 'Boomerang Economy', private investments and concessional loans by Japanese investors supported large-scale infrastructure and capital-intensive investments in developing countries (Seekins 2015). For example, in $2016,51.1 \%$ of bilateral Japanese ODA was used for economic infrastructure and services, while 59\% was for trade promoting incentives for developing countries (OECD 2018: 349). In addition, 
Japan's private enterprises play an important role in Japan's aid architectures beyond the Government-to-Government level. Around 38\% of Japan's multilateral ODA is privately funded in cooperation with the World Bank Group (ibid.: 347). Also, an increasing number of Japanese companies engage with local businesses in developing countries (ibid.: 346).

Japan's ODA has two principal aid modalities: Yen loan and technical cooperation. The former was implemented by the Japanese government in partnership with Japanese private enterprises. This public-private partnership (PPP) is also known as the 'flying goose' model of economic development. The PPP was formed as a vehicle for delivering Yen loan projects, which symbolise Japan's long-term commitment to and guarantee for continuing interest in the successful development of its investment destinations. In the area of infrastructure and development assistance, the PPP has been a driving force for Japan's ODA. On technical cooperation, the Japan International Cooperation Agency (JICA) has led numerous human resource development projects which contribute to empowering mid-space actors to function as bridge-builders and thus insider-partial mediators for their communities. Complementary collaboration between JICA and Japanese Non-Governmental Organisations (NGOs) in the execution of Japan's ODA is another spearhead of Japan's peacebuilding approach, which is called the ODANGO. In short, the twin engines of Japanese approaches are the PPP and the ODANGO.

It is undeniable that a large portion of Japan's ODA pours into economic development, concentrating on building key infrastructures to boost the economy of both Japan and developing countries. Japan's private sector collaborates with the Japanese government and continues to play a vital role in this endeavour (MOFA 2008). As Japan has located its PPP for economic development under the 'peace through development' narrative, it would be misleading to omit the contributions made by Japan's private companies to peacebuilding. While they have recently begun to undertake an increasing number of community development projects in conflict-affected areas, so far these projects involve only national actors and their interface with mid-space actors remains underexplored. 


\section{Three Recurrent Practices}

The recurrent practices of Japan's efforts can be classified into three: (1) apolitical nature, (2) request-based, and (3) non-interference. While they are closely intertwined with one another, all of them point to an underlying Westphalian virtue: primacy of Government-to-Government relationships.

Japan has been reluctant to get involved in politically sensitive issues. With this, Japan's ODA has kept an apolitical nature, revolving around Japanese expertise in areas of technical solutions and support. This practice is closely linked with Japan's emphasis on economic development, particularly through infrastructure development via Yen loans. In 2003, when the Japanese government revised its ODA Charter, it decided to use its foreign aid to facilitate democratic development abroad. Still, the approach remained distinctive from that of Western donors. Ichihara (2017) called this an "ostensible" departure from Japan's traditional policy as Japan's democratic support centred around helping state institutions, in effect avoiding unnecessary conflicts with the aid-recipient government.

The second recurring practice is that Japan's ODA projects are in principle formulated based on requests from the aid-recipient government. Although Japan can maintain a certain degree of leverage on the final decisions through offering advice and technical support to key figures in the aid-recipient government, this practice has given the aid-recipient governments a sense of security that Japan would not bluntly intrude into their internal terrain, which resulted in lowering their protective barrier of sovereignty.

The third practice is represented by Japan's non-interference stance, which enabled Japanese actors to engage in situations where access was denied for Western donors. This non-interference posture of Japan helped its peacebuilding actors gain an initial advantage by reducing suspicions in the minds of internationally isolated actors. On the contrary, Western donors suffered a deficit of trust due to their intrusive approach that exploited aid as a concealment for regulating the behaviour of an aidrecipient society so that it would follow 'universal' models/standards. The principle of non-interference, which can be traced back to the United Nations Charter (Chapter 1, Article 2.7), served as a Westphalian framework for Japan to invest in developing countries without criticising unpleasant policies of its counterpart. 


\section{Japan’s Peacebuilding Approaches in Practice}

Having outlined the orthodox features of Japan's peacebuilding efforts, it is now time to turn our attention to the core quest. While maintaining an orthodox approach of mainstreaming the Government-toGovernment interface, some Japanese actors made innovative departures from the recurring patterns in three distinctive peacebuilding settings in Asia-Timor-Leste, Myanmar and Mindanao. The records of Japanese engagement in these cases are scrutinised by focusing on the interaction of Japanese actors with mid-space actors who hold the capacities to bridge vertical, horizontal and diagonal gaps that hamper the peace process (Uesugi 2020).

Mid-space actors possess attributes of their unique social position that is rooted in access to varying sources of power and their deep cultural and normative understanding about the community they control. Acknowledging the importance of mid-space actors and their function of placing restrictions on the outreach of an outside agency can enhance the potential of external actors for working with local actors outside the immediate range of governmental control. This point is worth noting if one subscribes to an assumption that acquiring sufficient and accurate knowledge about the local context and dynamics is a prerequisite for successful outside intervention. Japan's official peacebuilding actors such as JICA have worked through the central government of an aidrecipient country, and often collaborated with Japanese NGOs to carry out projects at the grassroots. This pattern of partnership can face a difficult challenge, however, when the central government does not have its grip on subaltern communities at the grassroots level. Under such circumstances, for Japanese actors to operate in areas beyond the reach of the central government, they would have to earn the trust of mid-space actors and help them build bridges over existing cleavages.

The mid-space actor typology introduced in Chapter 4 of this study suggests that outsiders may support mid-space actors by empowering them as bridge-builders, often through offering them technical and political skills training, and sharing information that can widen their perspectives about the conflict dynamics and domains. Building upon the typology, this section explores the following two inquiries. How have Japanese actors and mid-space actors interacted with each other in the peacebuilding process? How have Japanese actors supported them to better serve as bridge-builders? To clarify these questions, the following 
section examines the empirical records of Japan's peacebuilding activities in Timor-Leste, Myanmar and Mindanao, where Japan has engaged in the capacity development of mid-space actors including key gatekeepers in the respective peacebuilding processes.

\section{Timor-Leste}

\section{Background}

Japan's engagement in Timor-Leste was unprecedented as Japanese actors started their support to Timor-Leste before Timor-Leste became independent in May 2002. The conventional approach of Japan's ODA was based on the Government-to-Government agreement. Nonetheless, before a sovereign authority was established in Timor-Leste (except that the UN Transitional Administrator was given the legal authority to govern by the UN Security Council), the Japanese government set the priority of its support to Timor-Leste in three areas: (1) human resource development, (2) infrastructure rehabilitation, and (3) rural development. Although none of JICA's projects had specific features of peacebuilding (JICA 2008: 12), they were introduced under the 'fast-track' scheme to meet the urgent needs on the ground. JICA initially hesitated to extend its support to security and justice sectors as it was understood that Western donors were interested in engaging in these sectors where Japan's resources and expertise were limited (ibid.: 14). Accordingly, many humanitarian aid and development projects delivered by the Japanese actors including NGOs were apolitical in nature.

In Timor-Leste, the timing of Japan's intervention went against convention, but the repertoire of its peacebuilding efforts remained unvaried. After all, the basic philosophy of Japan's peacebuilding engagement was that any humanitarian aid and development projects could contribute to peace in a post-conflict society (MOFA 2011). For example, Japanese Ambassador Iwao Kitahara proudly stated, under the banner of 'water of life', that providing clean water for all could reduce the risk of children being infected by illness, and claimed that "if people are healthy, so is the country" (Embassy of Japan in Timor-Leste 2009).

\section{Engagement with Mid-Space Actors}

Nevertheless, there were two innovative approaches made by Japanese actors to engage with mid-space actors in Timor-Leste. The first case was initiated by the Self-Defence Forces (SDF) who were deployed to 
the United Nations Mission of Support in East Timor (UNMISET). The second initiative was led by a Japanese NGO called the Okinawa Peace Assistance Center (OPAC).

Japan deployed its SDF engineering unit to UNMISET, authorised under Chapter VII of the UN Charter to take all the necessary means to achieve its mandate. Although Japan's engagements were limited to non-coercive activities, it was the first time that Japan sent its SDFs to a UN peacekeeping operation acting under Chapter VII. SDF's engineers deployed to UNMISET took part in an innovative programme named the Recovery, Employment, and Stability Program for Ex-combatants and Communities in Timor-Leste (RESPECT) that aimed to address some of the immediate needs of mid-space actors in the rural areas of TimorLeste. RESPECT encompassed over 300 projects that were funded by the Japanese government, channelled through the United Nations Development Programme (MOFA 2011). SDF engineers who were deployed on the ground to undertake rehabilitation of damaged infrastructures were mobilised to offer 'technical support', or more precisely on-the-job training, to former members of a liberation army called the FALINTIL. Because of their long-term commitment as guerrilla fighters in the jungle, many of the FALINTIL senior members were in poor physical condition and had a weak education background, and thus more than 1,300 former FALINTIL combatants were not recruited in a newly established defence force and the police (Uesugi 2014a; Howe and Uesugi 2015).

After independence in May 2002, FALINTIL veterans who felt neglected raised their voices against their government. They became a major source of instability in a newly born state as they maintained their influence over their former cadets and members of the community. Therefore, Japan's attempt to engage with frustrated mid-space actors through RESPECT had the potential to evolve into a sound peacebuilding strategy. Nevertheless, RESPECT did not go beyond a stop-gap measure to provide livelihoods (daily allowance) to mid-space actors in Timor-Leste, albeit it was conceived as a capacity development opportunity for former combatants to facilitate their reintegration into the civilian life (MOFA 2011: 96). Japan's involvement remained at the superficial level and no Japanese actors were available to follow up the initial contacts with mid-space actors developed through this undertaking. In 2006, frustrated actors both inside and outside the security apparatus turned against 
the peacebuilding process and led their followers to cause a security disturbance in Dili that shook the earlier investments and achievements in the security sector of Timor-Leste (Uesugi 2014b, 2018a).

The next example of Japan's engagement in the mid-space was attempted by OPAC, which was founded by one of the authors of this chapter. While most of the Japanese NGOs which operated at the grassroots level in Timor-Leste followed the conventional Japanese approach, OPAC together with JICA launched an unprecedented project called the Community Peace for Development in 2010 (which lasted until 2016). Before the launch, OPAC had worked with JICA in 2002, 2005, 2006, 2009 , and 2010 , inviting around 25 prominent mid-space leaders from Timor-Leste to Japan each time for training (over 125 trainees in total). The trainees included, for example, district administrators (an equivalent of a governor), civil servants, police officers, village chiefs, NGO representatives, youth group leaders and former members of the clandestine movement (OPAC, n.d.).

Building on the multiple networks developed through these training programmes, OPAC earned the trust of two key local counterparts of the project: (1) the National Directorate for Prevention of Community Conflict (NDPCC), that was under the Secretary of State for Security, and (2) the Comoro Village Council (Higuchi 2013). The NDPCC was established in 2008 after the Government of Timor-Leste failed to prevent the crisis in 2006, with an aim of preventing community-level conflicts from posing threats to the nation-wide stability (Ribeiro 2008). One of the major concerns for the NDPCC at the time of joint project planning was fragile security situations in Comoro Village, located at the outskirts of the capital city where a large number of youth from various rural areas gathered to find jobs, and several martial arts groups (gangs) were organised to offer a sense of protection and belonging to vulnerable people who were away from home (Lopes 2009).

After consultation with the NDPCC leadership, OPAC's assistance for the NDPCC's effort to address the security concerns in Comoro Village was divided into two: (1) national level efforts geared toward capacity development of mid-space actors, and (2) sub-national level efforts revolved around establishing platforms for information sharing through multi-level networks (Higuchi 2013). OPAC extended its support to build platforms and networks for dialogue among mid-space actors at the national level, which included the staff of the NDPCC, the Secretary of 
State for Youth, various national NGOs specialising in conflict prevention, youth organisations, and district and sub-district police commanders (OPAC 2011).

This initiative led to the institutionalisation of the Conflict Prevention and Response Network (CPRN) which brought together both state and civil society actors in Timor-Leste working toward peacebuilding (Belun 2014; da Costa 2013: 32-35). Upon the launch of the CPRN, an NGO called the Belun, established with support from the Center for International Conflict Resolution at Columbia University, played an important role (Cutter et al. 2004). Because OPAC was collaborating with both the NDPCC (a government actor) and the Belun (a civil society actor), a national-level platform for dialogue was constructed rather smoothly.

OPAC's second major activity was implemented in Comoro Village, where repeated skirmishes between rival martial art groups occurred frequently (Scambary 2019: 122). Upon the introduction of activities aimed at contributing to conflict prevention in Comoro Village, OPAC consulted with the Comoro Village Council. One of the highlights of OPAC's sub-national level activity, implemented jointly with the NDPCC, was a village-wide workshop on conflict prevention that received endorsements from the Comoro Village Council and a local monastery. In the workshop, mid-space actors such as traditional leaders (liurai), representatives from youth and women's organisations, and leaders of martial arts groups, all assembled in one place to analyse the security challenges they faced and discuss ways to overcome them (OPAC 2011).

Even though the effects of OPAC's intervention are unverifiable and it is difficult to establish the causal relationship, OPAC sought to institute contacts with mid-space actors, whilst a decade was invested in nurturing relationship and earning their trust before the project was launched officially.

At the same time, the CPRN was kept as a consultation and information sharing forum at the national level, and no formal mechanism was institutionalised between the national level and the sub-national level in the CPRN. While bridge-building support made by OPAC could have been amplified to cover a much wider geographical range beyond Comoro Village, such attempts did not bear fruit and OPAC's efforts were limited in terms of their impact and the scope. Therefore, what OPAC endeavoured in the mid-space in Comoro Village cannot be generalised as Japan's peacebuilding approach in Timor-Leste. Still, this case deserves 
more than a passing notice as it demonstrates that approaches elicited from the hybrid peacebuilding theory would work in a real situation.

\section{Myanmar}

\section{Background}

Japanese engagement in Myanmar, particularly after the military coup d'état in 1988, has deviated from that of the West. It provided much needed support for Myanmar in times of diplomatic isolation and economic decline (Seekins 1992; Reilly 2013). Although Japan had been one of the top donors among the Organisation for Economic Cooperation and Development (OECD) countries, it had to act in concert with the West when economic sanctions were placed on Myanmar. After the birth of democratic government in 2011 and with the sanctions being partially lifted, Japan resumed its ODA to Myanmar in 2012, which amounted to over $82 \%$ of the total foreign aid that Myanmar received from the OECD countries in 2013 (MOFA 2018).

Japan's flagship development aid to Myanmar has been Yen loans for infrastructure projects which aimed to promote sustainable economic development. Besides the major infrastructure projects that would support the central government's National Comprehensive Development Plan, Japan has allocated its ODA projects in Myanmar's border states where ethnic armed groups reside. Japan carries out its infrastructure projects under the PPP scheme, in which the Japanese private sector plays a pivotal role. For example, in 2013 JICA launched a Regional Development Project for Poverty Reduction that covered all seven states controlled by ethnic armed groups (i.e., Chin, Kachin, Karen, Kayah, Mon, Rakhine and Shan). In 2020, the Government of Myanmar and JICA signed loan agreement which included the Regional Infrastructure Improvement Project (JICA 2020a).

These projects are apolitical in nature as their expected outcomes included reducing poverty in and inequality among Myanmar's bordering states (JICA 2020b). At the same time, a new development was witnessed as these Yen loan projects were introduced in conflict-affected areas as a peace dividend, which had been avoided before as such an attempt could drag Japan into a politically challenging situation. 


\section{Engagement with Mid-Space Actors}

One of the most noteworthy peacebuilding approaches in Myanmar can be found in efforts made by The Nippon Foundation (TNF), a Japanese NGO (to be more precise, public interest incorporated foundation), which has operated in Myanmar since 1976 (TNF, n.d.). Its humanitarian support in the areas of health and education continued even during the period of military rule in Myanmar (ibid.). In concert with the shift of the Japanese government's policy toward Myanmar in 2012, TNF began its quiet diplomacy in the area of Myanmar's ethnic conflicts. The Chairperson of TNF, Yohei Sasakawa, who was appointed as the Special Envoy of the Government of Japan for National Reconciliation in Myanmar in 2013, took advantage of TNF's four decades of commitment in the country when he started a peacebuilding project that aimed at fostering confidence-building between the central government and armed ethnic groups. To establish an initial contact with leaders of armed ethnic groups, he sought support from Katsuyuki Imoto, a Japanese Buddhist monk and the head of another Japanese NGO that was set up to collect ashes of former Japanese soldiers who died in Myanmar during the Battle of Imphal in 1944 (Nojima 2019). Imoto played an instrumental role in the launch of the United Nationalities Federal Council (UNFC), a coalition of 12 opposition groups, which created a united front to negotiate with the Myanmar's central government (Molloy, unpublished). Through this endeavour, Imoto earned the trust of not only gatekeepers in armed ethnic groups in Shan, Karen, Kayah and Mon States, but also of President Tein Sein who asked Imoto to serve as a go-between (ibid.; Imoto, n.d.).

Since then, TNF has supported a series of national dialogues among different stakeholders and adversaries, which had little guarantee of instant and visible outcomes. With self-sufficient financial resources at its disposal, TNF did not have to be accountable to donors, and thus had a luxury of operating with a long timeframe. It did not even need a 'success' story to attract further funding and to marshal sufficient financial resources to continue the project. It could afford to wait for the time to become ripe for the peace process to evolve naturally. This was a huge advantage of TNF acting as a reliable patron for mid-space actors, since most of the official peacebuilding actors of the OECD members, including those of Japan, had to be transparent and accountable to donors (and their tax payers) and were expected to bring positive results in a relatively short timeframe. In fact, unlike other actors, TNF did not have to 
claim its contribution to the peace process, which allowed it to operate from behind the scenes. It served as an enabler and convener of the peace dialogue by paying travel expenses on behalf of the armed ethnic groups, but it did not interfere with the substance of the peace dialogue (Mori 2018).

In concert with the progress made at the negotiation table, TNF provided positive incentive in a timely manner as a peace dividend for communities which signed a ceasefire agreement (Molloy, unpublished). Its combined funding scheme worked to its advantage, and its ability to deliver what was required gave TNF additional strengths. While TNF has its pooled fund at its disposal, since 2013 it has been granted funds from the Japanese government to provide humanitarian aid to the people in conflict-affected areas under the control of armed ethnic groups (TNF, n.d.).

Furthermore, being the Special Envoy of the Government of Japan as well as TNF's Chairperson, Sasakawa assumed a hybrid function and performed quiet multi-track diplomacy at all levels (Track 1, 2 and 3). He was in a position to manoeuvre his official capacity to marshal Japan's ODA and to link up with the highest-ranking officials in Myanmar's central government. At the same time, he could also distance himself from the official endeavours by the Japanese actors such as the Japanese Embassy and JICA in Myanmar to circumvent the situations that are diplomatically too sensitive.

Desmond Molloy (unpublished: 11), who served as an aid to Sasakawa in TNF's Myanmar Liaison Office describes TNF's approach as "Sustained Incremental Trust Establishment and Support", which is in essence a trust-building approach. TNF maintained its independence from the Western donors throughout the process, which enabled it to remain more adaptive and flexible to dynamics on the ground, while promoting various forms of peace dividend through a conflict sensitive approach (ibid.).

In addition to peace dialogue support in the field, TNF invested in human resource development of the Tatmadaw (the armed forces of Myanmar). Instead of criticising the Tatmadaw, TNF helped to initiate the necessary reform by themselves, believing that it was not wise to push them into a corner, which could have made them feel isolated and induced radical reactions. Each year since 2014, TNF invited around 10 highest-level commanders, including the Commander-in-Chief Min Aung Hlaing, of the Tatmadaw as well as high-ranking officers from the Ministry of Border Affairs (also under the control of the Tatmadaw), 
including the Minister Lt. Gen. Thet Naing Win and Lt. Gen. Ye Aung, to Japan (Sasakawa 2014; IUJ 2019a). TNF also funds a programme called the Training Program for Capacity Development for Leadership Potential for Government Officials at the Ministry of Border Affairs in Myanmar offered by the International University of Japan (IUJ 2019b). All these concerted efforts constitute Japanese investment in relationshipbuilding with Myanmar's mid-space actors as well as their empowerment and capacity development.

Let us recapitulate Japan's peacebuilding engagement with Myanmar's mid-space actors. The above discussion shows two points. First, it was essential that appealing incentives were provided to both the central government and the state governments (under the control of armed ethnic groups) to earn their trust so that Japanese actors were permitted a broader and deeper outreach in the bordering states in conflict with the Tatmadaw. Second, it was useful for Japanese actors to remain patient and stay within the parameters set by the central government so that they were not seen as demanding and threatening, while extending its altruistic support for the most vulnerable people in conflict-affected communities to help increase the legitimacy of mid-space actors who were inclined towards peace. The case of Japan's peacebuilding engagement in Myanmar was indicative of the fact that when disciplinary acts by the West can exert pressure on the recalcitrant gatekeepers to alter their behaviour, an alternative conciliatory approach based on long-term commitment and a trustworthy relationship can induce them to explore alternative options.

\section{Mindanao}

\section{Background}

Japan's engagement in Mindanao deserves special attention as it encompasses long and broad cooperation across various stakeholders, and includes not only development assistance but also mediation and facilitation services in the peace process. Japan's engagement in Mindanao departed from a more conventional style in December 2002 when Prime Minister Junichiro Koizumi announced the "Support Package for Peace and Stability in Mindanao" (Ochiai 2019; Ishikawa 2014; MOFA 2002).

Under the new policy, JICA employed both conventional and innovative approaches. The former revolved around the assistance provided to the Autonomous Region of Muslim Mindanao (ARMM), which was established in 1990 as an official sub-national entity responsible for the 
administration of the territory, based on the 1974 Tripoli agreement made between the Government of the Philippines (GPH) and the Moro National Liberation Front (MNLF). A more innovative approach was employed in the second peace process, this time with the GPH and the Moro Islamic Liberation Front (MILF), which is the focus of this section.

\section{Engagement with Mid-Space Actors}

Japan's innovative approaches to mid-space actors in Mindanao can be found in four domains. The first interaction was made possible with the launch of the MILF Bangsamoro Development Agency (BDA), an organisation created to undertake the formulation of the Bangsamoro Development Plan (JICA 2015a). The second connection was made through another MILF organisation called the Bangsamoro Leadership and Management Institute (BLMI), which served as a vehicle of capacity development for the MILF combatants and emerging gatekeepers. The third point of contact was developed through Japan's engagement in the International Monitoring Team (IMT) through which JICA's development experts were given access to non-permissive areas beyond the control of the central government. The fourth encounter was the Consolidation for Peace (COP) in Mindanao, a series of Track 1.5 mediation efforts created to provide opportunities for mid-space actors to exchange their views on the peace process (Ishikawa 2014: 87-92).

The BDA was established by the Central Committee of the MILF in 2002. While the BDA had close ties with the MILF, its leadership was not drawn directly from the MILF (Kilmesova 2015: 223). Instead BDA's leadership was composed of respected members in the Maguindanao area, many of whom were medical doctors and former members of the Bangsamoro Development Council, a civil society organisation (ibid.). In other words, the BDA consisted of various gatekeepers and assumed a leadership role in not only fulfilling its mandate of reconstruction, rehabilitation and development in the conflict-affected communities in Bangsamoro but also transforming itself as a key lynchpin for peacebuilding (Abubakar 2019: 194).

The BDA was recognised as Japan's legitimate counterpart for territories in Mindanao beyond the reach of the central government before the comprehensive peace agreements were signed between the GPH and the MILF. It gave Japan a channel to provide a peace dividend to conflictaffected communities in Bangsamoro to entice mid-space actors into the peace process. Japan also contributed to the capacity development of the 
BDA (JICA 2015b) and, through the BDA, Japanese actors such as the Japanese Embassy and JICA were able to implement a variety of grassroots development projects under the rubric of the Japan-Bangsamoro Initiatives for Reconstruction and Development (J-BIRD) for the most vulnerable people in conflict-affected areas in Bangsamoro (Kilmesova 2015: 224).

The BLMI was established as a dividend of an agreement between the GPH and the MILF (Conciliation Resources 2012). It was a training facility for MILF mid-space actors to enhance their capacities in preparation for the establishment of the new Bangsamoro Government (ibid.; Abubakar 2019; Mabasa 2018). The GPH contributed to the operational fees while the Japanese government, under the Grant Assistance for Grassroots Human Security Project, constructed the facility for the BLMI (ibid.; Felongco 2011). Under the Comprehensive Capacity Development Project for the Bangsamoro, JICA used the BLMI as a springboard to offer an alternative livelihood to the MILF combatants that could reinforce the efforts of the MILF gatekeepers who were supportive of the peace process (JICA 2017; 2018).

The IMT was established in October 2004 in response to the ceasefire agreement made between the GPH and the MILF in 2003. It is an unarmed cease-fire monitoring team originally composed of the military, police and civilian personnel from Malaysia, Brunei and Libya (MOFA 2010). Japan announced its participation in the IMT in July 2006 in a statement titled "Japan Takes a More Active Role in the Mindanao Peace Process" (MOFA 2006). Unlike other countries that have despatched their military or police officers to the IMT, Japan endeavoured to add a new department specialising in social and economic development to the IMT and send JICA personnel to that department, so that they would act as hinges of Japan's development assistance in conflict-affected areas in Bangsamoro. Through the IMT's activities of cease-fire monitoring, Japanese representatives were able to access deep into communities affected by conflict and communicate needed information on the ground back to the Japanese Embassy and the JICA office in Manila for project formulation (Uesugi 2015).

Because of this special engagement in the grassroots communities under the control of the MILF where access was not granted to ordinary aid workers, Japanese actors were able to establish regular contact with mid-space actors in the hinterland. Legitimate requests for support made by gatekeepers were transmitted, along with the situation analysis on the 
ground made by Japanese actors in the IMT, to the Japanese Embassy in Manila, which were often responded to with tangible measures under the banner of the J-BIRD in a timely manner. This combined effort helped Japanese actors to earn the trust of mid-space actors who were encouraged to support the peace process (ibid.).

The COP in Mindanao was another unprecedented attempt for JICA as it sought to engage itself with political exercises. Under the COP from January 2006 till June 2014 JICA organised six seminars with the Universiti Sains Malaysia (Ishikawa 2014; JICA 2019). The COP started as an opportunity for mutual learning among sub-national stakeholders from different conflicts in Asia-Mindanao, Aceh and Southern Thailand. In the first two seminars and the fourth seminar, the participants drawn from these conflict-affected areas shared their lessons (JICA 2014). The third seminar, which was held in 2008 when the official peace talks for Mindanao had been stalled, was given a special task to serve as an alternative channel to the official mediation process. The seminar focused on the peace process in Mindanao and the participants were limited to mid-space actors in Mindanao such as civil society representatives, religious leaders, scholars, journalists and government officials (ibid.). Sachiko Ishikawa (2014), who was JICA's interlocutor for the COP, argued that the COP provided an optimal platform for addressing needs and exchanging perspectives of the civil society actors in Mindanao. When the formal peace talks resumed as a result of the breakthrough summit meeting held in Japan in August 2011, the fifth seminar was held in January 2012 with Track 1 stakeholders such as representatives of the ARMM government, all governors in the ARMM, and Members of the Congress (JICA 2019). After the comprehensive peace agreements were signed in March 2014, the last seminar was held in Hiroshima, Japan, in June 2014, at which President Benigno S. Aquino III and MILF's Chairman Al Haj Murad Ebrahim were present. This time, the COP was set out to further solidify the work for an inclusive framework of the peace process in Mindanao, and remaining issues were discussed and trust relationships among the participating gatekeepers were consolidated (ibid.).

These COP sessions provided safe-space for formal and informal actors to interact with each other, which promoted mutual understanding and a pivotal shift in the recalcitrant gatekeepers' perspective, from isolation and power-hoarding to recognising the value of interaction and trustbuilding (Ishikawa 2014: 87-92). The COP broadened Japan's horizons 
of engagement, as Japanese actors such as JICA have been recognised as trust-worthy and productive contributors to the peace process. The COP took the advantage of existing family ties between actors in Malaysia and Mindanao that provided a basis for earning trust of mid-space actors (Ochiai 2019), who could reach out to various stakeholders outside their own immediate sphere. Their presence helped establish the COP and nurtured it as a broader and more resilient network of interaction and dialogue.

The most important function of the COP was that it provided platforms for mid-space actors to interact not only with each other but also with other key stakeholders at different levels and intermediaries from outside. It gave gatekeepers, who were not allowed to participate in the official peace talks, a channel to express their concerns. In effect, the COP functioned to bridge horizontal, vertical and diagonal gaps. Through this bridge, Japanese actors gained informal access to mid-space actors from different domains such as the MILF rebel community, the ARMM community and the Christian community, and a chance to build trust with them. For instance, two innovative Japanese ventures in Mindanao emerged through discussion with mid-space actors at the COP. The first one was the dispatch of JICA's staff to the IMT, and the second one was the channelling of Japan's ODA to conflict-affected areas in Bangsamoro through the BDA (Uesugi 2015).

A detailed analysis of the interaction between Japanese actors and midspace actors in Mindanao illuminates both strengths and existing gaps in Japanese approaches to peacebuilding. The lessons drawn from the case study of Mindanao are twofold. First, JICA has served as a spearhead of Japanese initiatives and has attempted various innovative measures which transcended recurrent patterns of Japan's peacebuilding practice. Second, JICA's innovative initiatives were designed to create a conducive environment for mid-space actors to interact with each other and exert their influence on the formal peace process, and they did not interfere with the substantive aspects of the peace process.

\section{Shortcomings OF JAPAN's ApProACH}

The previous section discussed innovative approaches of Japanese peacebuilding applied in Timor-Leste, Myanmar and Mindanao, which showcased ways that Japanese actors engaged with mid-space actors in conflict-affected zones. What the previous section did not cover includes 
shortcomings and negative effects/consequences of Japanese efforts. Hence, this section elucidates these unexplored aspects and suggests a way forward to overcome these shortcomings.

\section{Shortcomings}

The first limitation is associated with Japan's strength of being seen as non-threatening. Japanese actors are only allowed to enter into nonkinetic permissive environments. This principle also applies to Japanese SDF personnel as part of the pacifist doctrine enshrined in the Japanese Constitution (Dobson 2003). While this policy of staying away from coercive measures has reassured aid-recipient governments of Japan's altruistic motives for engagement, it severely limited the parameters within which Japanese actors were allowed to operate.

The second limitation is related to the fact that Japanese support is request-based, which gives the aid-recipient government decisional power about what projects are to be pursued and where (Uesugi 2014a: 215220). This practice prevented Japanese actors from reaching those who were diametrically opposing the aid-recipient government. In Mindanao, while the COP provided a platform for the rebel and governmental representatives to meet, it did not include representatives of certain key power holders. For example, 'warlord politicians' who had vested interests in the existing order and thus were hostile to the peace process that could shake their power-basis, were not integrated into various Japan's efforts such as the COP (Espesor 2017). It is beyond the scope of this chapter to verify the cognitive impact which Japanese engagement had on the perceptions of mid-space actors. Rather it seeks to shed light on the fact that Japanese actors in each case established diagonal relationships with mid-space actors and facilitated vertical as well as horizontal interactions constructively among them.

As the hybrid peacebuilding theory indicates, it is vital for peacebuilders to be able to engage with as many stakeholders as possible to bridge existing cleavages. Underestimating the problem of unequal representation of mid-space actors in the peace process and the influence of local power structures that involve actors other than the primary interlocutors at the negotiation table can reinforce existing gaps in the distribution of aid and development (Taniguchi 2019). As proven in the case of Timor-Leste, marginalised and frustrated groups can undermine peacebuilding endeavours and amplify disparities which already exist 
in a society rather than leading to equitable and sustainable growth (Mac Ginty 2008; 2010). Japan's avoidance of politically sensitive issues, as well as unequal distribution and accessibility of aid for a broad range of mid-space actors, can cause existing conflicts to deteriorate, by widening disparities on the ground, and furthering discrimination towards marginalised groups.

\section{A Step Forward}

The question is how to circumvent political, socio-economic and psychological blockages placed by the central government in the channels that lead to crucial mid-space actors in the hinterland, who are considered hostile to the incumbent government or the ongoing peace process. One way to avoid this central dilemma is to acknowledge that peacebuilding endeavours are inherently 'political' (Hughes 2012: 102-103). Development projects have an indirect socio-economic impact, and they can influence dynamics in the local context and reshape existing power relations. The decision over which project is to be implemented has significant political implications for the prospect of peacebuilding. Thus, as demonstrated in this chapter, Japanese actors can continue to utilise their humanitarian and development assistance as positive incentives to entice both the government and mid-space actors to move towards a peaceful settlement. Yet, they should be aware of the unintended political consequences that their apolitical intervention could bring, and keep their efforts responsive, adaptable and flexible in relation to the fluctuating political landscapes (de Coning 2018).

On this point, Japan should stay within accepted parameters and refrain from using the fact that peacebuilding is inherently political as an excuse to infringe upon the sovereign rights of other countries. Mutual trust remains a key factor for guaranteeing smooth execution of peacebuilding efforts. This brings us back to the dilemma of selectivity. The most pragmatic response is to uphold its long-term commitment and stay patient and tolerant towards slow progress in peace processes. While Japanese peacebuilding actors can mobilise reinforcement from the development community, including its private sector, they are essentially equipped with two tools for providing peace dividend: Yen loans and technical assistance. Japan needs to come up with more effective ways (including optimal combinations of various aid modalities and projects) to employ a set of 
incentives at its disposal to facilitate its access to and cultivate a trustrelationship with mid-space actors who have broken or dubious ties with the aid-recipient government. At the same time, Japan should be open to various types of possibilities for expanding its horizon and gaining deeper accesses to hidden mid-space actors in the hinterland.

\section{CONCLUSION}

This chapter adopted the typology of mid-space actors introduced in Chapter 4 to verify the overarching theoretical arguments of this book. It examined in what way Japanese peacebuilding actors operated in three conflict-affected areas focusing on their relationship-building attempts with gatekeepers, and how Japanese actors were able to approach and collaborate with them. Throughout the journey, this chapter strove to clarify where Japan already holds its potential for becoming a 'hybrid peacebuilding facilitator', a bridge between the Western interventionists style of peacebuilding and the anthropological approaches indispensable for realising emancipatory peacebuilding (Uesugi 2018b; Richmond 2018).

Mid-space actors such as FALINTIL veterans in Timor-Leste, commanders of the Tatmadaw and armed ethnic groups in Myanmar, and rebel commanders and warlord politicians in Mindanao were all considered 'illiberal' by the Western donors, as they did not root their leadership in rational or democratic legitimacy, but their source of power lay in their prestige and lineage. Thus, Western donors were reluctant to treat these actors as legitimate in their dialogue-building approaches. Although security and intelligence actors of the West do not hesitate to collaborate with these 'illiberal' elements, developmental actors of the West are usually covered with a façade and their ethical codes prohibit them from engaging with these actors. On the contrary, Japanese actors explored this turbulent passage by nurturing the relationship with these 'illiberal' mid-space actors. In this respect, the notions of 'non-interference' and 'apolitical' allowed Japanese actors to approach seemingly 'illiberal' gatekeepers. On this point, Japan has also utilised its private sector involvement in economic development to counter acts of spoiling by addressing material needs of gatekeepers and their community. Japan's distinctive stance on the primacy of trust-building through long-term commitment and mutual respect has worked well in the three cases examined in this chapter. 
By scrutinising Japan's ability to work between the central government and mid-space actors, and to fill the gaps between locally grounded approaches and those of Western donors, this chapter arrives at the conclusion that Japan has manifested its potential as a 'hybrid peacebuilding facilitator'. Japanese approaches were instrumental in bridging existing cleavages between mid-space actors and Western donors, which contributed to achieving emancipatory local ownership and sustaining peace in conflict-affected communities in Timor-Leste, Myanmar and Mindanao (Manantan and Simangan 2019).

Being a non-Western member of the OECD, Japan identifies itself as a bridge between the West and the Rest. This underlines Japan's self-identity as a bridge-building nation, which is represented by its "kakehashi" policy (Black 2013). Because Japan has been recognised as an integral part of the OECD or the Global North, its unique positionality and potential as a hybrid peacebuilding facilitator have been overlooked. But it does not mean that Japan can automatically claim such a role. Japan has demonstrated its capacity to act as a hybrid peacebuilding facilitator between Western approaches and locally grounded approaches in three specific cases in Asia. If Japan would be able to overcome its shortcomings such as the lack of inclusiveness and access to mid-space actors in the hinterland, Japan might be able to emerge as a full-fledged hybrid peacebuilding facilitator. While it is beyond the scope of this chapter to investigate Japan's peacebuilding involvement outside of Asia, if Japan can fulfil similar functions elsewhere, Japan could rightfully claim its role as a bridge between the West and the Rest.

\section{REFERENCES}

Abubakar, A. U. (2019). Peacebuilding and Sustainable Human Development: The Pursuit of the Bangsamoro Right to Self-Determination. Berlin: Springer. Belun. (2014). Conflict Transformation in Timor-Leste: A Study Case on Conflict Prevention and Response Network (CPRN) (Research Report). http://128. 199.253.240:8088/wp-content/uploads/2015/03/Belun-NGO-ResearchRep-August-2014_Final.pdf.

Black, L. (2013). Bridging Between Myanmar and International Society: Japan's Self-identity and Kakehashi Policy. The Pacific Review, 26(4), 337-359.

Conciliation Resources. (2012). Building Structure for Peace. https://www.c-r. org/news-and-insight/building-structures-peace. 
Cutter, A., Gruener, S., Vyavaharkar, S., \& Ximenes, L. (2004). Timor Leste Conflict Assessment (Final Report). http://128.199.253.240:8088/wp-con tent/uploads/2012/06/Timor-Leste-Conflict-Assessment-2004.pdf.

Da Costa, M. (2013). Strengthening Partnership to Present and Respond to Conflict: Through Belun Early Warning Early Response (EWER) Program. In Timor-Leste: Conflict Prevention and Peacebuilding at the Community Level (pp. 24-39). Ochanomizu University Global Collaboration Center. http:// www.cf.ocha.ac.jp/archive/cwed/publications/pub_08e.pdf.

de Coning, C. (2018, March). Adaptive Peacebuilding. International Affairs, 94(2), 301-317.

Dobson, H. (2003). Japan and United Nations Peacekeeping: New Pressures, New Responses. London: Routledge Curzon.

Embassy of Japan in Timor-Leste. (2009). Economy and Development Cooperation: Grant Assistance for Grassroots Human Security Projects (in Japanese), https://www.timor-leste.emb-japan.go.jp/ggp42.html.

Espesor, J. (2017). Waltzing with the Powerful: Understanding NGOs in a Game of Power in Conflict-Ridden Mindanao. Pacific Dynamics: Journal of Interdisciplinary Research, $1(1), 66-83$.

Felongco, G.P. (2011, November 19). Leadership and Management Training School for Moro Leaders to Rise in Maguindanao. World Asia. https://gulfnews.com/world/asia/philippines/leadership-and-manage ment-training-school-for-moro-leaders-to-rise-in-maguindanao-1.933514.

Higuchi, Y. (2013). JICA's Grassroots Technical Cooperation (CommunityInitiated Type): The Timor-Leste and Okinawa 'Community Peace for Development' Project. In Timor-Leste: Conflict Prevention and Peacebuilding at the Community Level (pp. 40-53). Ochanomizu University Global Collaboration Center. http://www.cf.ocha.ac.jp/archive/cwed/publications/pub_ 08e.pdf.

Howe, B., \& Uesugi, Y. (2015). The Legality and Legitimacy of UN Peacekeeping Missions in East Timor. Waseda Global Forum, 12, 81-107.

Hughes, B. (2012). Peace Operations and the Political: A Pacific Reminder of What Really Matters. Journal of International Peacekeeping, 16(1-2), 99-118.

Ichihara, M. (2017). Japan's International Democracy Assistance as Soft Power: Neoclassical Realist Analysis. New York: Routledge.

Ikeda, J. (2008). Japanese Vision of International Society: A Historical Exploration. In K. Shimizu, J. Ikeda, T. Kamino, \& S. Sato (Eds.), Is There a Japanese IR? Seeking an Academic Bridge Through Japan's History of International Relations (pp. 5-28). Research Series 5, Shiga: Afrasian Centre for Peace and Development Studies, Ryukoku University.

Imoto. K. (n.d.). Japan Myanmar Future Conference. https://teamimoto.jp. International University of Japan. (2019a). Union Minister for Ministry of Border Affairs Meets Myanmar Students. https://www.iuj.ac.jp/20190403-2-2/. 
International University of Japan. (2019b). Training Program for Government Officials at the Ministry of Border in Myanmar had been Implemented. https://www.iuj.ac.jp/20190809-2/.

Ishikawa, S. (2014). The Role of a Development Agency in Peacebuilding: Track One-and-a-Half Mediation in Mindanao. Asian Journal of Peacebuilding, 2(1), 79-95.

Iwami, T. (2016). Understanding Japan's Peacebuilding in Concept and Practice. East Asia, 33(2), 111-132.

JICA (Japan International Cooperation Agency) (Timor-Leste). (2008). JICA Timor-Leste Annual Report. https://www.jica.go.jp/easttimor/office/activi ties/ku57pq00001uyovv-att/annual_report2007.pdf.

JICA (Japan International Cooperation Agency) (Philippines). (2015a). Mindanao. https://www.jica.go.jp/project/english/philippines/009/out line/c8h0vm00009i0pzi-att/outline_12.pdf.

JICA (Japan International Cooperation Agency) (Philippines). (2015b). Mindanao. https://www.jica.go.jp/project/english/philippines/009/out line/c8h0vm00009i0pzi-att/outline_13.pdf.

JICA (Japan International Cooperation Agency). (2017, March 8). Press Release: JICA, PhilRice Training Program Graduates 362 Farmers in Former MILF Camps. https://www.jica.go.jp/philippine/english/office/topics/news/170 308.html.

JICA (Japan International Cooperation Agency). (2018, August 28). Press Release: More than 100 Farmer Combatants in Bangsamoro Graduate from JICA-PHILRICE Agri Training Program. https://www.jica.go.jp/philip pine/english/office/topics/news/180828.html.

JICA (Japan International Cooperation Agency). (2019). JICA's Assistance on Peace and Development in Mindanao. Tokyo: Japan International Cooperation Agency.

JICA (Japan International Cooperation Agency). (2020a). Ex-Ante Evaluation (Regional Infrastructure Improvement Project). https://www.jica.go.jp/ english/our_work/evaluation/oda_loan/economic_cooperation/c8h0vm000 001rdjt-att/myanmar_200121_04.pdf.

JICA (Japan International Cooperation Agency). (2020b). Press Releases: Signing of Japanese ODA Loan Agreements with Myanmar: Comprehensive Support for Economic and Social Development. https://www.jica.go.jp/english/news/ press/2019/20200121_10_en.html.

Kilmesova, M. (2015). Using Carrots to Bring Peace? Negotiation and Third Party Involvement. World Scientific.

Lopes, L. (2009). Interview with the director of the National Directorate for the Prevention of Community Conflict, the Secretary of State for Security, Democratic Republic of Timor-Leste. 
Mabasa, R. (2018, March 8). 41 MILF Middle Managers to Undergo Training. Manila Bulletin. https://news.mb.com.ph/2019/03/08/41-milfmiddle-managers-to-undergo-training/.

Mac Ginty, R. (2008). Indigenous Peace-Making Versus the Liberal Peace. Cooperation and Conflict, 43(2), 139-163.

Mac Ginty, R. (2010). Hybrid Peace: The Interaction Between Top-Down and Bottom-Up Peace. Security Dialogue, 41(4), 391-412.

Manantan, M., \& Simangan, D. (2019). Japan's Peacebuilding Prowess: The Case of Marawi City. The Diplomat. https://thediplomat.com/2019/06/jap ans-peacebuilding-prowess-the-case-of-marawi-city/.

MOFA (Ministry of Foreign Affairs of Japan). (2002, December 4). Support Package for Peace and Stability in Mindanao. https://www.mofa.go.jp/reg ion/asia-paci/philippine/pv0212/mindanao.html.

MOFA (Ministry of Foreign Affairs of Japan). (2006, July 23). Japan Takes a More Active Role in the Mindanao Peace Process. https://www.mofa.go.jp/ region/asia-paci/philippine/meet0607.html.

MOFA (Ministry of Foreign Affairs of Japan). (2007). Japan's Efforts on Peacebuilding: Towards Consolidation of Peace and Nation-Building. https://www. mofa.go.jp/policy/un/pko/effort0704.pdf.

MOFA (Ministry of Foreign Affairs of Japan). (2008). Japan's Official Development Assistance White Paper 2008. https://www.mofa.go.jp/policy/oda/ white/2008/part3-2-5.pdf.

MOFA (Ministry of Foreign Affairs). (2010, Feburary 26). Resumption of Dispatch of Development Experts to the International Monitoring Team in the Philippines. https://www.mofa.go.jp/announce/announce/2010/2/ 0226_01.html.

MOFA (Ministry of Foreign Affairs of Japan). (2011). Third Party Evaluation FY 2010: Evaluation of Assistance for Peace-Building (in Japanese). https://www.mofa.go.jp/mofaj/gaiko/oda/shiryo/hyouka/kun ibetu/gai/easttimor/hs10_01_index.html.

MOFA (Ministry of Foreign Affairs of Japan). (2018). Myanmar. Japan's ODA Data by Country. https://www.mofa.go.jp/mofaj/gaiko/oda/files/000142 547.pdf.

Molloy, D. (n.d.). A Hybrid Way to Do Peacebuilding: Sustained Incremental Trust Establishment and Support. Unpublished Paper.

Mori, Y. (2018, March 8). Interview with the head of International Cooperation Group. The Nippon Foundation, conducted at the Nippon Foundation Headquater in Tokyo.

Nojima, T. (2019). Myanmar Special Edition (4): Two Japanese Who Tackled with a Difficult Task of Brokering Peace with Ethnic Minorities from Behind the Scene (in Japanese). https://www.nippon.com/ja/japan-topics/c06204/. 
Ochiai, N. (2019). Philippine Mindanao, Peace and Development: The Way to Peace Through Trust. Tokyo: Saiki (in Japanese).

OECD. (2018). Development Co-operation Report 2018: Joining Forces to Leave No One Behind. https://www.oecd.org/social/development-co-operation-rep ort-20747721.htm.

OPAC (Okinawa Peace Assistance Center). (n.d.). International Peace Cooperation (in Japanese). http://www.opac.or.jp/ipc/index.html.

OPAC (Okinawa Peace Assistance Center). (2011). JICA's Grassroots Technical Cooperation (Community-Initiated Type): The Timor-Leste and Okinawa Community Peace for Development Project, The Report of the First Year Activities, an unpublished document submitted to JICA.

Reilly, J. (2013). China and Japan in Myanmar: Aid, Natural Resources and Influence. Asian Studies Review, 37(2), 141-157.

Ribeiro A. (2008). Interview with the founding director of the National Directorate for the Prevention of Community Conflict, the Secretary of State for Security, Democratic Republic of Timor-Leste.

Richmond, O. (2018). Rescuing Peacebuilding? Anthropology and Peace Formation. Global Society, 32(2), 221-239. https://doi.org/10.1080/13600826. 2018.1451828 .

Sasakawa, Y. (2014). Myanmar Armed Forces and the Minami Agency. https:// blog.canpan.info/sasakawa/archive/4760.

Scambary, J. (2019). Conflict, Identity, and State Formation in East Timor 20002017. Brill.

Seekins, D. (1992). Japan's Aid Relations with Military Regimes in Burma, 1962-1991: The Kokunaika Process. Asian Survey, 32(3), 246-262.

Seekins, D. M. (2015). Japan's Development Ambitions for Myanmar: The Problem of 'Economics before Politics'. Journal of Current Southeast Asian Affairs, 34(2), 113-138.

Taniguchi, M. (2019). Rethinking 'Liberal Peacebuilding': Conflict, Violence, and Peace in Mindanao. Social Transformations, 7(1), 165-193.

TNF (The Nippon Foundation). (n.d.). Myanmar Support Program. https:// www.nippon-foundation.or.jp/en/what/projects/myanmar.

Uesugi, Y. (2014a). All-Japan Approach to International Peace Operations. Journal of International Peacekeeping, 18(3-4), 214-235.

Uesugi, Y. (2014b). Security Sector Reform (SSR) in Timor-Leste: The Challenges of Respecting Local Ownership. Asia Peacebuilding Initiatives. http:// peacebuilding.asia/1057/.

Uesugi, Y. (2015). Coodination between Diplomacy and Development in the Mindanao Peace Process: The Use of 'Peace Dividends' and Roles of International Monitoring Team, World Studies (in Japanese), 63(10), 51-66. 
Uesugi, Y. (2018a). Neo-Authoritarian Peace in Timor-Leste. In B. Howe (Ed.), National Security, Statecentricity, and Governance in East Asia (pp. 107-126). Cham: Palgrave Macmillan.

Uesugi, Y. (2018b). Chapter 4 Platforms for Dialogue and Hybrid Facilitators in the Bangsamoro Peace Process. In M. Yamada \& M. Honda (Eds.), Complex Emergencies and Humanitarian Response (pp. 65-86). Osaka: Union Press.

Uesugi, Y. (2020). Introduction. In Y. Uesugi (Ed.), Hybrid Peacebuilding in Asia (pp. 1-14). Cham: Palgrave Macmillan.

Umesao T. (1957/1967) (translated by B. Cary and edited by H. Befu in 2003). An Ecological View of History: Japanese Civilization in the World Context. Trans Pacific Press.

Open Access This chapter is licensed under the terms of the Creative Commons Attribution 4.0 International License (http://creativecommons.org/licenses/ by $/ 4.0 /)$, which permits use, sharing, adaptation, distribution and reproduction in any medium or format, as long as you give appropriate credit to the original author(s) and the source, provide a link to the Creative Commons license and indicate if changes were made.

The images or other third party material in this chapter are included in the chapter's Creative Commons license, unless indicated otherwise in a credit line to the material. If material is not included in the chapter's Creative Commons license and your intended use is not permitted by statutory regulation or exceeds the permitted use, you will need to obtain permission directly from the copyright holder.

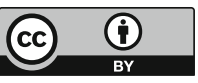

